\title{
MEMBERDAYAKAN GURU UNTUK MELAKSANAKAN 'PROJECT CITIZEN” DALAM RANGKA PENDIDIKAN KARAKTER BANGSA
}

\author{
oleh, \\ Sukadi \\ Fakultas Ilmu Sosial \\ Universitas Pendidikan Ganesha
}

\begin{abstract}
ABSTRAK
Kegiatan P2M ini bertujuan memberdayakan guru-guru IPS dan PKn pada SMP dan SMA/SMK di Kota Singaraja untuk dapat mengimplementasikan model pembelajaran Project Citizen dalam pembelajaran di kelas sebagai wahana pendidikan karakter bangsa. Untuk tujuan ini guru-guru diberikan diklat model pembelajaran Project Citizen selama 20 jam, mengimplementasikan di kelas, dan mengikuti kegiatan showcase hasil portofolio siswa. Hasilnya, guru-guru dapat menerapkan model pembelajaran Project Citizen ini dalam pembelajaran IPS dan PKn di kelas sebagai wahana pendidikan karakter siswa dengan baik. Siswa juga dapat meningkatkan hasil belajarnya yang berorientasi pendidikan karakter, antara lain meliputi: pemahaman konseptual; kemampuan pemecahan masalah-masalah sosial kewarganegaraan; kepekaan dan komitmen terhadap lingkungan sosial kewarganegaraan; orientasi nilai dan sikap kewarganegaraan; serta beberapa keterampilan sosial kewarganegaraan siswa, seperti: komunikasi, presentasi, kerja sama, sharing tanggung jawab kepemimpinan, kemampuan mendistribusi tugas, mengatasi konflik, dan keterampilan berkompetisi.
\end{abstract}

Kata-kata kunci: project citizen, pendidikan karakter, hasil belajar siswa

\begin{abstract}
This community service activity was aimed at empowering the Social Studies and Civic Education teachers at SMP and SMA/SMK in Singaraja in order to conduct the Project Citizen model in their teaching in the class as a vihicle of national character education. For this objective, the teachers were trained in using the Project Citizen model for 20 hours long, applied this model of teaching in their class, and then conducted students portfolio showcase. The results, the teachers could practice the Project Citizen model in their Social Studies and Civic Education teaching as a vehicle of character education propoundly. Besides, the students could improve their learning output on the basis of character education, namely: in their conceptual comprehension, problem solving capacity, commitment to social and civic environment, civic attitude and values orientation, and in their civic skills such as: in communicating, presenting, working together, sharing in leadership responsibility, distributing tasks, solving conflict, as well as in doing competition.
\end{abstract}

Key words: project citizen, character education, student learning output

\section{Pendahuluan}

Sejak tahun 2010 Pemerintah Indonesia merevitalisasi pendidikan karakter bangsa dalam rangka kemandirian bangsa. Betapa pentingnya pendidikan karakter bangsa 
direvitalisasi bagi generasi muda di era globalisasi ini. Ini berkaitan dengan makin mendegradasinya karakter generasi muda dari identitas nasional bangsa Indonesia, yakni Pancasila. Kenyataannya, di era globalisasi ini karakter bangsa Indonesia yang berkepribadian Pancasila ternyata hanyalah utopia belaka. Dalam realitanya, karakter bangsa Indonesia dewasa ini, terutama generasi mudanya, ternyata dinilai jauh dari nilai-nilai Pancasila, UUD 1945, NKRI, dan Bhinneka Tunggal Ika. Pemeritah Republik Indonesia (2010:16-19) menilai bahwa dewasa ini bangsa Indonesia memiliki masalah besar dalam pembangunan karakter bangsa.

Begitu akutnya masalah ini, seorang dalang di Bali (dikenal sebagai dalang Ceng Blong) dengan cerita humornya memberi penilaian bahwa masyarakat Indonesia dewasa ini sudah kurang menerapkan Pancasila melainkan lebih menerapkan Pancasala (panca = lima, sala = keanehan karena kebodohan), yaitu: keuangan yang maha kuasa, kemanusiaan yang rakus dan biadab, perseteruan Indonesia, kerakyatan yang dipimpin oleh nikmat kemaksiatan dalam persekongkolan (KKN: korupsi, kolusi, dan nepotisme) dan perwakilan, serta kemelaratan sosial bagi seluruh masyarakat kecil Indonesia.

Pendidikan di sekolah ditengarai berkontribusi pada degradasi karakter bangsa di kalangan generasi muda dewasa ini. Pendidikan nasional yang semestinya bertujuan mencerdaskan kehidupan bangsa dengan membangun karakter manusia Indonesia seutuhnya, malah menjadi program pendidikan yang lepas dari nilai-nilai karakter dan budaya bangsa Indonesia. Widja (2009) menyatakan telah terjadi proses reduksionis dalam pelaksanaan program pendidikan di Indonesia dari pendidikan yang semestinya berorientasi dan bertujuan mengembangkan karakter dan budaya bangsa Indonesia menuju program pendidikan kapitalis, pendidikan berorientasi sertifikat/diploma, pendidikan yang lepas dari akar budaya bangsa Indonesia.

Ciri program pendidikan seperti itu antara lain adalah: tujuan pembelajaran cenderung hanya untuk penguasaan konsep-konsep keilmuan; materi pembelajaran hanya dikembangkan sesuai isi buku teks keilmuan ilmiah yang hanya bermuatan konseptual dan kurang menekankan materi nilai, moral, dan pemecahan masalahmasalah secara kontekstual; proses pembelajaran gaya bank yang bersifat konvensional yang hanya menekankan kegiatan ekspositori konsep; sumber belajar yang berbasis keilmuan tingkat rendah yang kurang bermakna; kering dari media pembelajaran yang mendidik; evaluasi hasil belajar yang cenderung berorientasi pemerolehan skor ranah kognisi tingkat rendah saja; serta tidak berbasis refleksi dan evaluasi diri (Sukadi, 2010: Landrawan dan Sukadi, 2009).

Praktik pembelajaran di kelas-kelas pembelajaran IPS dan PKn di sekolah pada umumnya dan di kota Singaraja pada khususnya tidak luput dari praktik pendidikan 
reduksionis tersebut. Praktik Pendidikan IPS dan PKn yang sesungguhnya memiliki visi, misi, dan tujuan nation and character building ternyata tak lebih dari pengajaran konsep-konsep ilmu-ilmu sosial dan ilmu negara tingkat rendah dengan sasaran dan tujuan pembelajaran berorientasi penguasaan konsep tingkat $\mathrm{C} 1$ (kemampuan to recall) dan C2 (kemampuan to understand) saja. Pembelajaran aspek-aspek afeksi (seperti: keyakinan, nilai-nilai, komitmen, rasa percaya diri/self esteem, konsep diri/self-concept, dan sikap) dan keterampilan sosial kewarganegaraan yang bermakna cenderung terabaikan. Akibatnya, mata pelajaran IPS dan PKn menjadi sangat terkenal menjadi mata pelajaran hafalan konsep-konsep sosial dan kewarganegaraan yang cenderung memberatkan dan membosankan siswa. Maka tak mungkinlah diharapkan pembelajaran IPS dan PKn seperti ini membawa misi pendidikan karakter bangsa.

Tim peneliti jurusan PPKN Undiksha telah melakukan penelitian tentang pembelajaran IPS dan PKn yang memungkinkan guru mengintegrasikan pendidikan karakter bangsa. Sukadi (2005), misalnya, telah melakukan penelitian yang mengadopsi dan mengadaptasi model "project citizen" di Amerika untuk diterapkan dalam pembelajaran PKn pada siswa SMA di kota Singaraja. Sukadi (2006; 2010) juga pernah menerapkan model yang sama dalam pembelajaran Pendidikan Pancasila dan PKn pada mahasiswa jurusan Geografi dan PPKn IKIP Negeri Singaraja serta mahasiswa Jurusan Pendidikan Biologi dan D3 Akuntansi Undiksha. Tim CCEI Provinsi Bali (2002) juga pernah menerapkan model pembelajaran ini pada pembelajaran PKn di tingkat SMP. Hasilnya, di samping meningkatkan hasil belajar pemahaman konseptual para peserta didik, pembelajaran dengan model "project citizen" yang diadaptasi dengan nama Praktik Belajar Kewarganegaraan-Kami Bangsa Indonesia ... (PBK-KBI) antara lain juga dapat meningkatkan: antusiasme siswa dalam belajar PKn; sikap positif siswa dalam pembelajaran PKn; motivasi belajarnya; rasa percaya diri dan konsep dirinya (self-confidence dan self-concept); kreativitas siswa; kemampuan berpikir tinggi (berpikir kritis dan pemecahan masalah); kepekaan dan komitmen terhadap lingkungan sosial kewarganegaraan; dan beberapa keterampilan sosial siswa, seperti: komunikasi, presentasi, kerja sama, sharing tanggung jawab kepemimpinan, kemampuan mendistribusi tugas, mengatasi konflik, dan keterampilan berkompetisi.

Atas dasar keberhasilan inilah tim mengajukan proposal untuk melakukan kegiatan P2M dalam rangka memberdayakan guru-guru IPS dan PKn pada tingkat SMP dan SMA/SMK di kota Singaraja dalam melakukan project citizen dalam rangka pendidikan karakter bangsa. Dalam kegiatan P2M ini tim akan memberikan kegiatan diklat kepada guru-guru PKn dan kelompok IPS dari tingkat SMP hingga SMA/SMK tentang pelaksanaan model project citizen dalam pembelajaran IPS dan PKn di kelas, 
melakukan pembinaan kepada guru-guru di lapangan, dan memberikan kesempatan kepada semua guru untuk mengikuti kegiatan showcase project citizen bagi para siswanya dalam sebuah kompetisi tingkat SMP dan SMA/SMK di kota Singaraja. Dengan kegiatan P2M ini paling tidak diharapkan guru-guru IPS dan PKn dapat meningkatkan kemampuan profesionalnya dalam melakukan pendidikan karakter bangsa melalui kegiatan pembelajaran di kelas yang bermuatan misi pendidikan karakter bangsa.

Atas dasar permasalahan di atas dapatlah dirumuskan permasalahan utama dalam kegiatan P2M ini sebagai berikut. (1) Apakah pemberdayaan dan pembinaan kepada guru-guru untuk melaksanakan model project citizen dalam pembelajaran IPS dan PKn dapat dijadikan wahana untuk integrasi pendidikan karakter bangsa di kelas?. dan (2) Bagaimana output penerapan model project citizen sebagai wahana pendidikan karakter bangsa terhadap hasil belajar siswa dalam pembelajaran IPS dan PKn pada tingkat SMP dan SMA/SMK secara terintegrasi dalam ranah-ranah: pemahaman konseptual, kemampuan pemecahan masalah-masalah sosial kewarganegaraan, kepekaan dan komitmen terhadap lingkungan sosial kewarganegaraan; orientasi nilai dan sikap kewarganegaraan, serta beberapa keterampilan sosial kewarganegaraan siswa, seperti: keterampilan berkomunikasi, presentasi, kerja sama, sharing tanggung jawab kepemimpinan, kemampuan mendistribusi tugas, mengatasi konflik, dan keterampilan berkompetisi?

Secara umum kegiatan P2M ini bertujuan memberdayakan guru-guru IPS dan PKn tingkat SMP dan SMA/SMK di kota Singaraja untuk dapat menerapkan model pembelajaran project citizen di kelasnya masing-masing dalam upaya integrasi pendidikan karakter bangsa. Secara khusus tujuan P2M ini adalah sebagai berikut. (1) Memberdayakan dan membina guru-guru IPS dan PKn tingkat SMP dan SMA/SMK di kota Singaraja untuk melaksanakan model project citizen dalam pembelajaran IPS dan PKn untuk dapat dijadikan wahana integrasi pendidikan karakter bangsa di kelas, dan (2) Membantu guru-guru mencapai dampak penerapan model project citizen sebagai wahana pendidikan karakter bangsa terhadap hasil belajar siswa dalam pembelajaran IPS dan PKn pada tingkat SMP dan SMA/SMK secara terintegrasi dalam ranah-ranah: pemahaman konseptual, kemampuan pemecahan masalah-masalah sosial kewarganegaraan, kepekaan dan komitmen terhadap lingkungan sosial kewarganegaraan; orientasi nilai dan sikap kewarganegaraan, serta beberapa keterampilan sosial kewarganegaraan siswa, seperti: komunikasi, presentasi, kerja sama, sharing tanggung jawab kepemimpinan, kemampuan mendistribusi tugas, mengatasi konflik, dan keterampilan berkompetisi. 
Project citizen awalnya dikembangkan oleh Center For Civic Education (CCE) Calabasas California di Amerika Serikat sebagai model kurikulum for Civic Education dalam rangka meningkatkan kesadaran berdemokrasi peserta didik dalam kehidupan bermasyarakat, berbangsa, dan bernegara. Model ini kemudian disebarluaskan dan dikembangkan ke berbagai negara termasuk di Indonesia. Model Project Citizen mulanya dikembangkan di Amerika adalah sebagai a curricular program at the middle school through adult levels promoting competent and responsible participation with government at all levels. The program helps participants learn how to monitor and influence public policy while developing support for democratic values and principles, tolerance, and feelings of political efficacy (http://new.civiced.org/pc-program).

Jelaslah dari penjelasan tersebut bahwa project citizen adalah sebuah program kurikuler Pendidikan Kewarganegaraan untuk siswa remaja dan orang dewasa yang mendorong mereka belajar berbasis projek dalam rangka studi isu-isu kebijakan publik. Dalam program ini siswa belajar secara kooperatif pada level kelas untuk mengidentifikasi, menganalisis, mengevaluasi, dan merumuskan usul-usul kebijakan publik yang diajukan kepada pejabat pemerintahan di berbagai level (lokal, kabupaten, propinsi, nasional, dan internasional). Hasil belajar mereka umumnya didokumentasikan dalam bentuk portofolio. Portofolio ini kemudian dipresentasikan dihadapan kelas lain, atau diajukan kepada pejabat pemerintahan terkait. Dalam portofolio terdokumentasi: masalah-masalah sosial kewarganegaraan atau isu-isu kebijakan publik yang dapat diidentifikasi, usul strategi pemecahan masalah, usulan rumusan kebijakan publik, dan rencana aksi. Untuk mendapatkan produk portofolio ini proses belajar yang dilakukan para siswa umumnya meliputi: mengidentifikasi masalah-masalah kebijakan publik; mengumpulkan, menganalisis, dan mengevaluasi informasi; mengkaji dan mengevaluasi berbagai alternatif pemecahan masalah kebijakan publik; mengevaluasi dan merumuskan usulan kebijakan publik yang terbaik; merumuskan action plan; mendokumentasikan produk belajar ke dalam portofolio; mempresentasikan portofolio dalam suatu showcase; dan melaksanakan tindakan partisipatif untuk mewujudkan lebijakan publik (CCEI, 2003, 2004).

Model pembelajaran project citizen diyakini dapat dijadikan model integrasi pendidikan karakter bangsa dalam pembelajaran IPS dan PKn di kelas. Hal ini mengingat model pembelajaran ini melibatkan aktivitas belajar siswa secara multidimensi. Siswa tidak hanya terlibat dalam aktivitas studi secara akademis melainkan juga terlibat dalam aktivitas-aktivitas: fisik dan emosional, intelektual, sosial, 
moral, dan spiritual. Belajar yang melibatkan aktivitas secara multidimensi ini diyakini dan dibuktikan oleh Devries dan Zan (1994) dapat membangun karakter peserta didik secara utuh. Belajar seperti inilah yang dinyatakan oleh tim Kementerian Pendidikan Nasional (2011) sebagai belajar yang melibatkan aktivitas olah raga, olah rasa, olah pikir, olah hati, dan olah iman.

Menjelaskan bahwa penerapan model pembelajaran project citizen dapat mengintegrasikan misi pendidikan karakter bangsa bukanlah hanya utopia belaka. Beberapa hasil penelitian dan pelaksanaan P2M telah menunjukkan harapan-harapan di atas. Sukadi $(2007: 755$; 2010) dalam penelitiannya pada mahasiswa jurusan PPKn dan Pendidikan geografi menunjukkan bahwa penerapan model PBK-KBI dapat meningkatkan pemahaman konseptual mahasiswa, kemampuan berpikir akademis, meningkatkan rasa percaya diri dan konsep diri, meningkatkan kepekaan dan komitmen sosial kewarganegaraan, dan meningkatkan beberapa aspek keterampilan sosial mahasiswa.

Begitu pula Penelitian Sukadi (2005: 8-10) melaporkan bahwa penerapan PBK-KBI pada siswa kelas X di SMA Lab. IKIP Negeri Singaraja dapat meningkatkan kecakapan personal dan sosial siswa secara terbatas yang meliputi aspek-aspek: rasa percaya diri dan konsep diri, kemampuan presentasi, kesediaan mendengarkan pendapat orang lain, sharing tanggung jawab kepemimpinan, kemampuan berkomunikasi, dan kemampuan bekerja sama. Tim CCEI Provinsi Bali (2002) melaporkan kegiatan P2Mnya dalam bentuk pelatihan dan pembinaan model PBK-KBI kepada guru-guru IPS dan PKn di Bali yang menunjukkan bahwa pembelajaran dengan model "project citizen" yang diadaptasi dengan nama Praktik Belajar Kewarganegaraan-Kami Bangsa Indonesia ... (PBK-KBI) antara lain dapat meningkatkan: hasil belajar pemahaman konseptual para peserta didik; antusiasme siswa dalam belajar; sikap positif siswa dalam pembelajaran; motivasi belajarnya; rasa percaya diri dan konsep dirinya (self-confidence dan selfconcept); kreativitas siswa; kemampuan berpikir tinggi (berpikir kritis dan pemecahan masalah); kepekaan dan komitmen terhadap lingkungan sosial kewarganegaraan; dan beberapa keterampilan sosial siswa, seperti: komunikasi, presentasi, kerja sama, sharing tanggung jawab kepemimpinan, kemampuan mendistribusi tugas, mengatasi konflik, dan keterampilan berkompetisi. 


\section{Metode Pelaksanaan Pengabdian}

P2M ini dilaksanakan dalam tiga tahap kegiatan, yaitu: tahap diklat 20 jam, tahap implementasi di kelas oleh guru-guru, dan tahap siswa mengikuti kegiatan showcase portofolio sebagai hasil belajarnya yang berorientasi pendidikan karakter. Subjek sasaran P2M ini adalah kepala sekolah dan guru-guru IPS/PPKn pada tingkat SMP dan SMA/SMK di kota Singaraja. Jumlah subjek adalah 25 orang. Evaluasi kegiatan dilakukan baik menggunakan pendekatan formatif maupun sumatif dengan penilaian secara kualitatif (Popham, 1974). Indikator keberhasilan P2M ini adalah guru-guru dapat menerapkan model project citizen dalam pembelajaran IPS/PPKn di kelas dengan baik sebagai wahana pendidikan karakter bangsa. Kedua, hasil belajar siswa yang berorientasi pendidikan karakter juga meningkat.

\section{Hasil dan Pembahasan}

Pelaksanaan P2M ini sudah dapat dilakukan dengan baik. Ini terbukti dari guruguru IPS dan PPKn SMP dan SMA/SMK di kota Singaraja sudah dapat menerapkan model pembelajaran project citizen dalam pembelajarannya di kelas dengan baik. Dari segi proses dapat diketahui bahwa penerapan model project citizen dalam pembelajaran IPS / PPKn baik di tingkat SMP maupun SMA/SMK di kota Singaraja dapat digunakan sebagai wahana belajar pendidikan karakter bangsa.

Dari segi hasil pelaksanaan, penerapan model project citizen dapat membantu meningkatkan hasil belajar siswa yang berorientasi pendidikan karakter secara utuh, antara lain dapat meningkatkan: pemahaman konseptual, kemampuan pemecahan masalah-masalah sosial kewarganegaraan, kepekaan dan komitmen terhadap lingkungan sosial kewarganegaraan; orientasi nilai dan sikap kewarganegaraan, serta beberapa keterampilan sosial kewarganegaraan siswa, seperti: komunikasi, presentasi, kerja sama, sharing tanggung jawab kepemimpinan, kemampuan mendistribusi tugas, mengatasi konflik, dan keterampilan berkompetisi.

Hasil P2M ini, dengan demikian, relevan dengan teori dan temuan yang mendasari pengembangan model pembelajaran project citizen, yang dapat diargumentasikan sebagai berikut. Pertama, model pembelajaran project citizen diyakini dapat dijadikan model integrasi pendidikan karakter bangsa dalam pembelajaran IPS dan PKn di kelas. Hal ini mengingat model pembelajaran ini melibatkan aktivitas belajar siswa secara 
multidimensi. Siswa tidak hanya terlibat dalam aktivitas studi secara akademis melainkan juga terlibat dalam aktivitas-aktivitas: fisik dan emosional, intelektual, sosial, moral, dan spiritual. Belajar yang melibatkan aktivitas secara multidimensi ini diyakini dan dibuktikan oleh Devries dan Zan (1994) dapat membangun karakter peserta didik secara utuh. Belajar seperti inilah yang dinyatakan oleh tim Kementerian Pendidikan Nasional (2011) sebagai belajar yang melibatkan aktivitas olah raga, olah rasa, olah pikir, olah hati, dan olah iman.

Aktivitas fisik dan emosional dilakukan oleh siswa dalam model pembelajaran project citizen ketika mereka harus melakukan pengumpulan data dan informasi dari berbagai sumber baik di sekolah maupun di masyarakat. Pengalaman belajar secara nyata ini memberikan pengalaman yang menyenangkan kepada siswa. Begitu pula aktivitas belajar lainnya yang dilakukan secara bebas, mandiri, berkelompok, adanya kompetisi atau showcase, kegiatan curah pendapat dengan para pejabat terkait, dan pemberian penghargaan membuat pembelajaran ini menarik, menantang, dan menyenangkan. Pengalaman belajar yang menarik, menantang, tetapi juga menyenangkan tentu akan memberikan energi dan semangat belajar yang lebih bagi siswa. Siswa akan sangat antusias, peduli dan peka, dan tentu dapat mengembangkan komitmen dan rasa percaya dirinya.

Aktivitas intelektual secara akademis dilakukan siswa dengan melibatkan kemampuan berpikir tingkat tinggi dan kreativitas dalam model pembelajaran project citizen terjadi ketika para siswa belajar melakukan inkuiri, mengumpulkan dan menganalisis data, membuat alternatif pemecahan masalah, membuat usulan kebijakan publik, mengembangkan rancana aksi, dan melakukan presentasi. Kegiatan-kegiatan belajar seperti ini tentu akan dapat menumbuhkan kebiasaan siswa untuk gemar membaca, meningkatkan rasa ingin tahu, mengembangkan kemampuan berpikir kritis dan kreatif serta inovatif, belajar berorientasi produk, mengembangkan karakter diri yang ulet, teliti atau cermat, antusias, tangguh, disiplin, dan tentu jujur.

Aktivitas sosial terjadi dalam model pembelajaran project citizen ketika siswa belajar berkelompok secara kooperatif, belajar berkomunikasi dengan masyarakat dan dengan para pejabat pemerintahan terkait, belajar mempresentasikan dan mengkomunikasikan gagasan dan produk belajar kepada orang lain, belajar mendengarkan dan menghargai pendapat orang lain, belajar sharing tanggung jawab kepemimpinan, belajar mendistribusikan tugas kepada orang lain, belajar memecahkan konflik bersama, dsb. Kegiatan-kegiatan belajar yang dibiasakan seperti ini tentu akan dapat membentuk karakter kepedulian dan kepekaan kepada orang lain dan kepada masyarakat, karakter kepemimpinan, bersikap toleran, rendah hati, bersikap demokratis, 
bekerja sama dan gotong royong, kemampuan berkompetisi secara sehat, dan mengembangkan dasar-dasar jiwa patritisme dan ansionalisme.

Aktivitas moral terjadi, selanjutnya, ketika para siswa belajar mengidentifikasi konflik nilai dan kepentingan dalam isu kebijakan publik, belajar membuat pertimbangan-pertimbangan nilai dan moral dalam proses klarifikasi nilai dan moral, belajar membuat keputusan moral sebagai landasan usul kebijakan publik, belajar menyakinkan orang lain atas usul kebijakan yang ditawarkan siswa, dan belajar melakukan tindakan moral yang relevan dalam upaya mewujudkan usul kebijakan publik. Belajar secara moral seperti ini menuntun siswa memadukan pikiran, ucapan, dan tindakan yang baik dan bijaksana yang dapat membantu siswa meningkatkan rasa percaya diri dan konsep diri, membangun komitmen yang kuat, meningkatkan kepedulian dan kepekaan kepada orang lain dan masyarakat, meningkatkan wawasan dan orientasi nilai kebangsaan, lebih jujur, rendah hati, taat kepada norma-norma, menjunjung tinggi nilai-nilai keadilan, dsb.

Terakhir, aktivitas religius atau spiritual juga dapat terjadi dalam model pembelajaran project citizen. Ini dimulai dengan mengembangkan tujuan belajar yang berbasis ibadah kepada masyarakat, bangsa, negara, dan ibadah kepada Tuhan Yang maha Esa (Sukadi, 2009, 2010b, 2011); mengambil keputusan nilai dan moral atas landasan nilai-nilai moral dan spiritual yang diyakini: mengambil keputusan atas dasar nilai-nilai kebenaran, keadilan, dan kebijaksanaan; belajar berorientasi produk yang dapat diibadahkan kepada kepentingan orang banyak (masyarakat, bangsa, dan negara); dan belajar mengembangkan kebudayaan sendiri berbasis nilai-nilai kearifan lokal. Landasan nilai-nilai moral dan spiritual seperti ini tentu akan dapat menuntun siswa untuk mengembangkan karakter religius secara bermakna.

Kedua, menjelaskan bahwa penerapan model pembelajaran project citizen dapat mengintegrasikan misi pendidikan karakter bangsa bukanlah hanya utopia belaka. Beberapa hasil penelitian dan pelaksanaan P2M telah menunjukkan harapan-harapan di atas. Sukadi $(2007: 755$; 2010) dalam penelitiannya pada mahasiswa jurusan PPKn dan Pendidikan Geografi menunjukkan bahwa penerapan model PBK-KBI dapat meningkatkan pemahaman konseptual mahasiswa, kemampuan berpikir akademis, meningkatkan rasa percaya diri dan konsep diri, meningkatkan kepekaan dan komitmen sosial kewarganegaraan, dan meningkatkan beberapa aspek keterampilan sosial mahasiswa.

Begitu pula Penelitian Sukadi (2005: 8-10) melaporkan bahwa penerapan PBK-KBI pada siswa kelas X di SMA Lab. IKIP Negeri Singaraja dapat meningkatkan kecakapan personal dan sosial siswa secara terbatas yang meliputi aspek-aspek: rasa percaya diri 
dan konsep diri, kemampuan presentasi, kesediaan mendengarkan pendapat orang lain, sharing tanggung jawab kepemimpinan, kemampuan berkomunikasi, dan kemampuan bekerja sama.

Tim CCEI Provinsi Bali (2002) melaporkan kegiatan P2Mnya dalam bentuk pelatihan dan pembinaan model PBK-KBI kepada guru-guru IPS dan PKn di Bali yang menunjukkan bahwa pembelajaran dengan model "project citizen" yang diadaptasi dengan nama Praktik Belajar Kewarganegaraan-Kami Bangsa Indonesia ... (PBK-KBI) antara lain dapat meningkatkan: hasil belajar pemahaman konseptual para peserta didik; antusiasme siswa dalam belajar; sikap positif siswa dalam pembelajaran; motivasi belajarnya; rasa percaya diri dan konsep dirinya (self-confidence dan self-concept); kreativitas siswa; kemampuan berpikir tinggi (berpikir kritis dan pemecahan masalah); kepekaan dan komitmen terhadap lingkungan sosial kewarganegaraan; dan beberapa keterampilan sosial siswa, seperti: komunikasi, presentasi, kerja sama, sharing tanggung jawab kepemimpinan, kemampuan mendistribusi tugas, mengatasi konflik, dan keterampilan berkompetisi .

Demikianlah dapat diterima bahwa penerapan model pembelajaran project citizen dalam pembelajaran IPS dan PPKn pada tingkat SMP dan SMA/SMK di Kota Singaraja dapat dijadikan wahana pendidikan karakter bangsa. Model pembelajaran ini jika dapat diterapkan dengan baik akan meningkatkan hasil belajar siswa yang berorientasi pendidikan karakter secara utuh, antara lain dapat meningkatkan: pemahaman konseptual, kemampuan pemecahan masalah-masalah sosial kewarganegaraan, kepekaan dan komitmen terhadap lingkungan sosial kewarganegaraan; orientasi nilai dan sikap kewarganegaraan, serta beberapa keterampilan sosial kewarganegaraan siswa, seperti: komunikasi, presentasi, kerja sama, sharing tanggung jawab kepemimpinan, kemampuan mendistribusi tugas, mengatasi konflik, dan keterampilan berkompetisi.

\section{Penutup}

Sesuai dengan pelaksanaan P2M yang telah dilakukan sebelumnya dapatlah disimpulkan hasilnya sebagai berikut. Pertama, penerapan model pembelajaran project citizen dalam pembelajaran IPS dan PPKn pada tingkat SMP dan SMA/SMK di Kota Singaraja dapat dijadikan wahana pendidikan karakter bangsa. Kedua, model pembelajaran ini jika dapat diterapkan dengan baik akan meningkatkan hasil belajar siswa yang berorientasi pendidikan karakter secara utuh, antara lain dapat meningkatkan: pemahaman konseptual, kemampuan pemecahan masalah-masalah sosial kewarganegaraan, kepekaan dan komitmen terhadap lingkungan sosial kewarganegaraan; orientasi nilai dan sikap kewarganegaraan, serta beberapa 
keterampilan sosial kewarganegaraan siswa, seperti: komunikasi, presentasi, kerja sama, sharing tanggung jawab kepemimpinan, kemampuan mendistribusi tugas, mengatasi konflik, dan keterampilan berkompetisi.

\section{DAFTAR PUSTAKA}

DeVries, Rheta and Betty Zan. 1994. Moral Classrooms, Moral Children: Creating a Constructivist Atmosphere in Early Education. New York and London: Teachers College Press.

Doni Koesoema. 2007. Pendidikan Karakter: Strategi Mendidik Anak di Zaman Modern. Jakarta: PT Grasindo.

Kementerian Pendidikan Nasional. 2011. Naskah Akademik Pendidikan karakter di Perguruan Tinggi. Jakarta: Dirjen Dikti.

Landrawan, I W. Dan Sukadi. 2009. Pendidikan Kewarganegaraan dalam Dilema Ujian Akhir Nasional pada SMA di Kota Singaraja (Studi tentang Belajar, Pembelajaran, dan Penilaian di Kelas). Laporan Penelitian (Tidak dipublikasikan). Singaraja: Undiksha.

Pemerintah Republik Indonesia. 2010. Pembangunan Karakter Bangsa Tahun 20102025: Desain Induk. Jakarta: Tanpa Penerbit.

Popham, W.J. 1974. Evaluation in Education: Current Applications. California: MrGutrhau Publishing Corporation.

Sukadi. 2011. Rekonstruksi Pemikiran Belajar dan Pembelajaran PKn SD sebagai Yadnya dalam rangka Perwujudan Dharma Agama dan Dharma Negara Berbasis Konstruktivisme. Laporan Penelitian Tahun Ketiga (Tidak dipublikasikan). Singaraja: Undiksha.

.......... 2010. Pembelajaran PKn yang Demokratis dan Powerful melalui Model Proyek Kewarganegaraan pada Mahasiswa Universitas Pendidikan Ganesha. Laporan Teaching Grant (Tidak dipublikasikan). Singaraja: Undiksha.

2010b. Rekonstruksi Pemikiran Belajar dan Pembelajaran PKn SD sebagai Yadnya dalam rangka Perwujudan Dharma Agama dan Dharma Negara Berbasis Konstruktivisme. Laporan Penelitian Tahun Kedua (Tidak dipublikasikan). Singaraja: Undiksha.

2009. Rekonstruksi Pemikiran Belajar dan Pembelajaran PKn SD sebagai Yadnya dalam rangka Perwujudan Dharma Agama dan Dharma Negara Berbasis Konstruktivisme. Laporan Penelitian Tahun Pertama (Tidak dipublikasikan). Singaraja: Undiksha.

2007. Praktik Belajar Kewarganegaraan - Kami Bangsa Indonesia. Singaraja: Undiksha.

2006. Praktik Belajar Kewarganegaraan Berbasis Kebijakan Publik dan Peningkatan Kecakapan Kewarganegaraan Mahasiswa dalam rangka Implementasi Kurikulum Berbasis Kompetensi di IKIP Negeri Singaraja. Laporan Teaching Grant (Tidak dipublikasikan). Singaraja: Undiksha.

2005. Implementasi Model Praktik Belajar Kewarganegaraan dan Peningkatan Penguasaan Life Skills Siswa (Studi Reflektif pada Siswa Kelas X SMA Laboratorium IKIP Negeri Singaraja). Laporan Penelitian (Tidak dipublikasikan). Singaraja: Undiksha. 
Tim CCEI Provinsi Bali. (2002). Implementasi Praktik Belajar Kewarganegaraan pada SLTP di Bali. Laporan Hasil Observasi (Tidak dipublikasikan). Singaraja: CCEI.

Undang-undang Republik Indonesia Nomor 20 Tahun 2003 tentang Sistem Pendidikan Nasional. Jakarta: Depdiknas RI.

Widja, I G. 2009. Pendidikan sebagai Ideologi Budaya: Suatu Pengantar ke Arah Pendidikan Kritis. Denpasar: Kajian Budaya Universitas Udayana. 